\title{
PRELIMINARY OBSERVATIONS ON TWO ROCK GLACIERS IN SOUTH GEORGIA, FALKLAND ISLANDS DEPENDENCIES
}

\author{
By Richard V. BIRNIE* and Gordon Thom ${ }^{\dagger}$ \\ (Department of Geography, University of Aberdeen, Aberdeen AB9 2UF, Scotland)
}

\begin{abstract}
Two rock glaciers are described from the maritime sub-Antarctic island of South Georgia. The Cooper Sound rock glacier is a spatulate feature, probably ice-cored, $1.5 \mathrm{~km}$ long, and developed below a dissected cirque headwall. The Binary Peaks rock glacier is a lobate feature, possibly ice-cemented, only $175 \mathrm{~m}$ long, and contiguous with the talus behind it. Evidence for an ice-cored rock glacier in this maritime environment indicates that the debris supply and receiving glacier areas may be more important factors in determining rockglacier development than zonal climate.
\end{abstract}

RÉSUMÉ. Observations préliminaires sur deux glaciers rocheux à South Georgia, Falkland Islands Dependencies. On décrit deux glaciers rocheux l'île de South Georgia dans la zone maritime sous-antarctique. Le glacier rocheux de Cooper Sound, est en forme de spatule, avec probablement un coeur de glace, mesure $1,5 \mathrm{~km}$ de long et se développe au pied de la muraille d'un cirque découpé. Le glacier rocheux de Binary Peaks est en forme de lobe, est peut être liẻ par de la glace, mesure seulement $175 \mathrm{~m}$ de long, et est contiguë avec le talus derrière lui. Les preuves de l'existence d'un glacier rocheux à coeur de glace dans cet environnement maritime montrent que l'approvisionnement en matériaux et la surface glaciaire de réception peuvent être des facteurs plus importants dans le développement des glaciers rocheux que le climat général de la zone.

Zusammenfassung. Vorläufige Beobachtungen an zwei Blockgletschern in South Georgia, Falkland Islands Dependencies. Zwei Blockgletscher auf der maritimen, subantarktischen Insel von South Georgia werden beschrieben. Der Cooper-Sound-Blockgletscher ist eine schaufelförmige Erscheinung, vermutlich mit Eiskern. $1.5 \mathrm{~km}$ lang, entwickelt unter einem zergliederten Karmoränenwall. Der Binary-Peaks-Blockgletscher hat LobusForm, ist möglicherweise mit Eis zementiert, nur $175 \mathrm{~m}$ lang, und steht in Verbindung mit dem Schutthang dahinter. Das Auftreten eines Blockgletschers mit Eiskern in dieser maritimen Umgebung weist darauf hin, dass die Schuttzufuhr und die aufnehmenden Gletscherareale wichtigere Faktoren bei der Entwicklung von Blockgletschern sein könnten als das zonale Klima.

\section{INTRODUCTION}

The aim of this paper is to present preliminary observations made of two rock glaciers on the sub-Antarctic island of South Georgia. Subsequent interpretation covers the possible origins and types of these rock glaciers.

\section{BACKGROUND}

South Georgia is the largest island in the Scotia arc, lying about $1500 \mathrm{~km}$ to the north-east of the Antarctic Peninsula (Fig. 1). It is a narrow island, $170 \mathrm{~km}$ long, dominated by the mountains of the Allardyce and Salvesen Ranges which reach 2934 m (Mount Paget).

The climate of South Georgia is primarily determined by its position south of the Antarctic Convergence, in a zone of prevailing westerlies (Pepper, 1954). However, the mountains impose a strong influence on local weather patterns which results in the west coast having much higher

\footnotetext{
* Present address: Remote Sensing Unit, Department of Peat and Forest Soils, Macaulay Institute for Soil Research. Craigiebuckler, Aberdeen AB9 2QJ, Scotland.

† Present address: 16 Sedgewood Close, Hayes, Bromley, Kent BR2 7QL, England.
} 


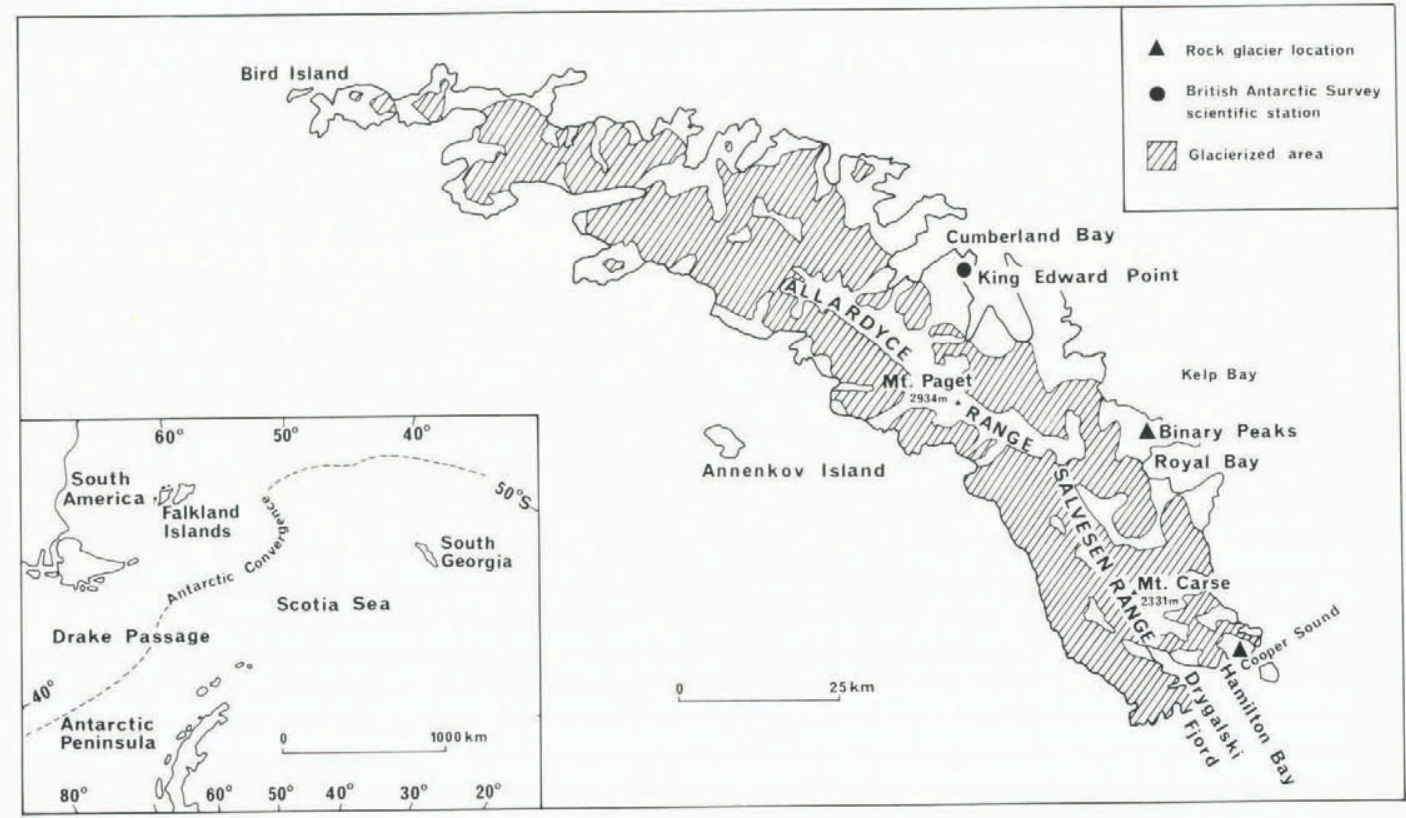

Fig. 1. Map showing location of rock glaciers with respect to the ice-free areas of South Georgia.

precipitation than the east coast (Smith, 1960[b]). Extreme maximum temperatures of $21^{\circ} \mathrm{C}$ on the east coast are associated with föhn winds. The British Antarctic Survey scientific station at King Edward Point, located in the lee of the Allardyce Range, returned 5.6 oktas for average cloud cover and $1699 \mathrm{~mm}$ (water equivalent) for total precipitation in 1975. Mean monthly air temperatures for the period $1971-75$ gave a maximum of $+5.6^{\circ} \mathrm{C}$ in February and a minimum of $-1.5^{\circ} \mathrm{C}$ in June. The mean annual temperature in this area is $+2.1^{\circ} \mathrm{C}$ and this should be fairly representative of the north-eastern coastal area as a whole (cf. Richards and Tickell, 1968). Geologically, South Georgia is a detached block of continental crust composed largely of turbidites of late Mesozoic age (Bell and others, 1977). A small igneous complex centres around Drygalski Fjord (Fig. 1). Both the igneous and sedimentary rock types have undergone severe deformation and are highly fractured. This makes them particularly susceptible to weathering (Skidmore, 1972) and examples of catastrophic failure have been recorded (Gordon and others, 1978).

About $58 \%$ of South Georgia is at present ice-covered (Smith, 1960[b]), with the bulk of the lower-lying ice-free areas restricted to the north-east coast (Fig. 1). Geomorphological mapping of these ice-free areas by members of the Department of Geography, University of Aberdeen, revealed a number of pro-talus landforms (Birnie, unpublished). The majority of these were single ridge features but two examples of multi-ridge rock-glacier features were discovered. The first occupies the floor of a south-facing cirque, $2 \mathrm{~km}$ to the east of Hamilton Bay and overlooking Cooper Sound (Fig. 1). The second is developed on the south-east flanks of Binary Peaks in the Royal Bay area (Fig. 1). The rock glaciers are derived from igneous and sedimentary source rocks, respectively. 


\section{COOPER SOUND ROCK GLACIER}

The Cooper Sound rock glacier comprises a tongue-like mass of rock debris extending $1.5 \mathrm{~km}$ down-valley from beneath the cirque headwall, widening from $200 \mathrm{~m}$ at its head to $500 \mathrm{~m}$ at its terminus (Fig. 2). The feature lies between $200 \mathrm{~m}$ and $57 \mathrm{~m}$ a.s.l. (height determined with Reynolds aneroid type B373), and has an average surface slope of $12^{\circ}$. Many superficial ridges exist on the upper surface of the rock glacier. Near its head these run longitudinally but become transverse down-slope, with an arcuate plan form (Figs 2 and 3). Individual ridges are 5-8 $\mathrm{m}$ high and have steep slopes between $35^{\circ}$ and $40^{\circ}$ on their down-glacier sides.

In general, the surface debris is coarse with a wide size range from less than $10 \mathrm{~cm}$ to several metres in diameter. Finer debris is only exposed along the steep slopes which occur around the margin of the rock glacier or on actively failing slopes on the upper surfaces. All the size components are angular and consist of mixed ultrabasic and basic rocks which reflect the variety of types exposed in the cirque headwall.

The rock glacier can be divided into four areas on the basis of morphological and vegetational differences (Fig. 2). In an attempt to determine vegetational differences, measurements were made of lichen thalli. The following procedure was adopted: sample sites were chosen near the middle (in terms of altitude) of each area; the largest thallus on 25 separate stones was measured; only the green lichens (Rhizocarpon sp., probably geographicum) were

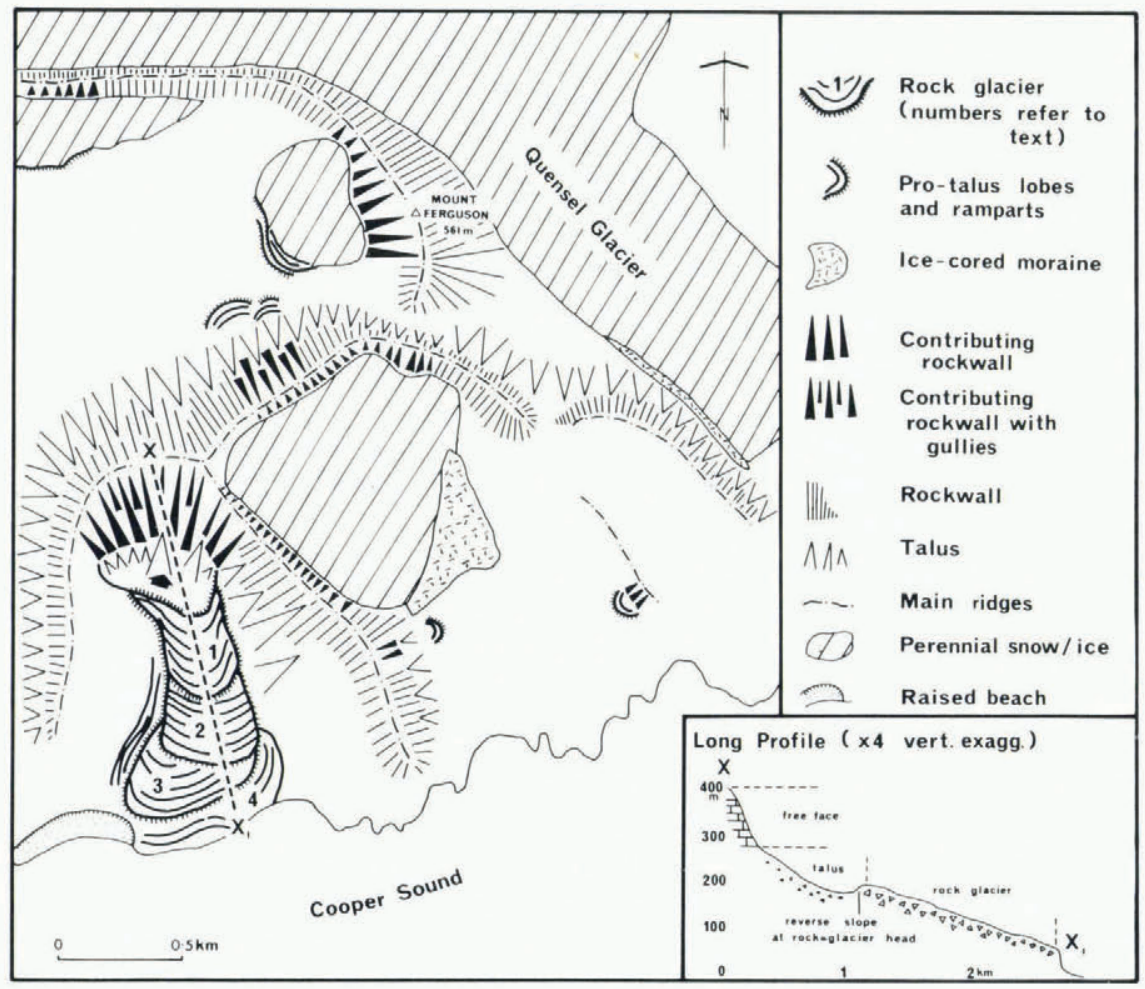

Fig. 2. Location and geomorphic setting of Cooper Sound rock glacier. (Based on 1974 air photography by HMS Endurance). The arrow indicates the area behind the rock-glacier head which receives most rock debris. 


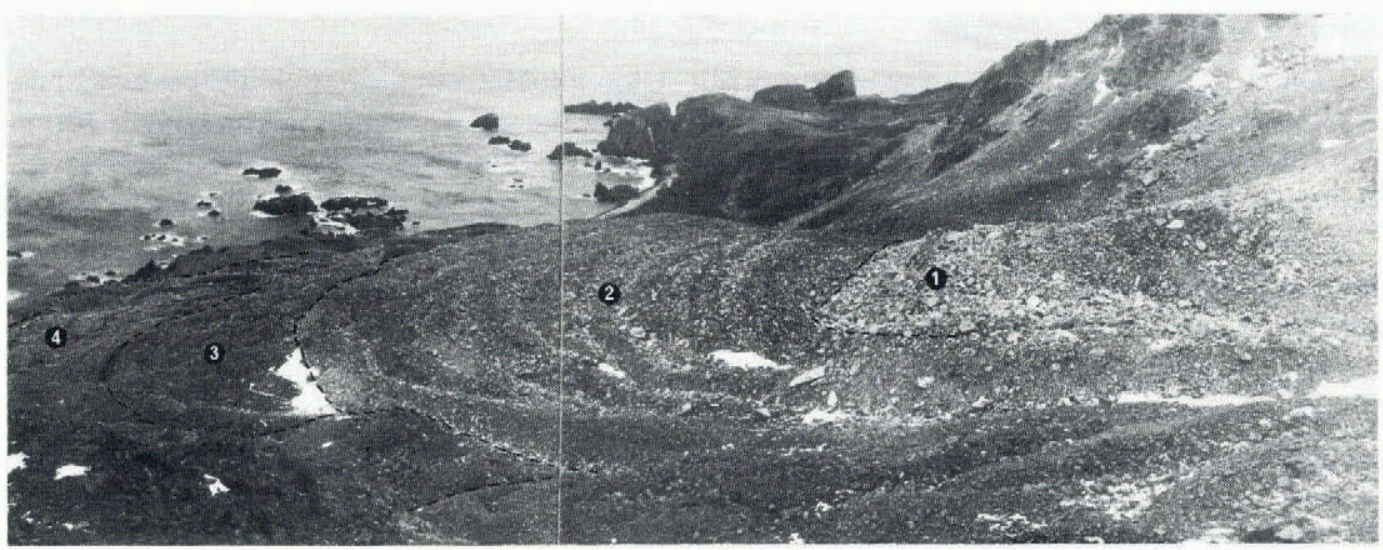

Fig. 3. View south-west across the Cooper Sound rock glacier. The contributing rockwall lies off the photograph to the right. The reverse slope at the head of the feature and the most recent deposits (area I) are clearly picked out by the lighter colour of the unweathered surface debris. The oldest deposits comprise a series of degraded ridges on the extreme left.

used and only those on clasts of feldspathic gabbro. Despite the attempts to eliminate errors due to local factors influencing lichen growth, the resulting lichen counts are likely to give an incomplete measure of age differences between sites (due to the effect of altitude on lichen growth), and are presented here purely as a guide to relative differences between the four areas of the rock glacier. The following descriptions of these areas also include other site attributes such as general vegetation cover and the thickness of weathering rinds on surface rocks. The characteristics of the four areas are as follows:

(1) The upper part of the rock glacier lies between $200 \mathrm{~m}$ and $175 \mathrm{~m}$ a.s.l. The debris is characterized by a light grey colour reflecting its unweathered nature. The longitudinal surface ridges are angular in cross-profile and terminate at a distinct break of slope marked by a steep ramp. This ramp rides over the more weathered surface debris of area (2). The surface stones have no weathering rind and vegetation in this upper area is restricted to two kinds of crustose lichen, providing less than a $1 \%$ cover on most rocks. The lichen count gave a mean diameter of $2.8 \mathrm{~cm}$ with a range of $1.3-4.2 \mathrm{~cm}$.

(2) The second area lies below the ramp described above. It descends from $167 \mathrm{~m}$ to $119 \mathrm{~m}$ a.s.l. where another, less well-defined break in slope occurs. The ridges in this area are transverse and arcuate down-slope (Fig. 3), with more rounded cross-profiles than the ridges of area (1). The surface stones have a grey weathering rind, generally less than $1 \mathrm{~mm}$ thick. At least three different kinds of crustose lichen are common, covering up to $25 \%$ of individual rock surfaces, and mosses are present in a few sheltered niches. The lichen count gave a mean diameter of $4.8 \mathrm{~cm}$ with a range of $3.7-6.0 \mathrm{~cm}$.

(3) Below the break of slope beneath area (2), the surface ridges are still transverse but are lower and have more rounded cross-profiles than area (2). The vegetation cover is up to $75 \%$, comprising a moss and lichen community. Whereas individual lichen thalli are identifiable in areas (1) and (2), here the encrustations interdigitate. Weathering rinds are generally over $1 \mathrm{~mm}$ thick and are sufficiently well developed to obscure lithological differences in the surface rocks. The lichen count gave a mean diameter of $4.7 \mathrm{~cm}$ with a range of $3.5-5.9 \mathrm{~cm}$. 
(4) The outer limits of the rock glacier comprise a series of degraded, transverse ridges, between $2 \mathrm{~m}$ and $6 \mathrm{~m}$ high and well vegetated. These extend from $100 \mathrm{~m}$ down to $57 \mathrm{~m}$ a.s.l. and at some points these ridges are being undercut by the marine-cut cliffs below. Sections at the top of these cliffs reveal that the ridge debris overlies a sequence of till deposits. The vegetation cover on the outer ridges is almost $100 \%$ with a greater diversity of species than on the higher areas, although mosses and lichens still dominate. Tussock grass (Poa flabellata) grows on the outermost ridges. Surface rocks are well weathered with rinds over $1 \mathrm{~mm}$ thick. The lichen count gave a mean diameter of $4.8 \mathrm{~cm}$ with a range of $3.9-5.9 \mathrm{~cm}$.

Most of the upper part of the rock glacier is at present separated from the cirque headwall by a depression about $20 \mathrm{~m}$ deep, $200 \mathrm{~m}$ across and up to $150 \mathrm{~m}$ wide. The slope leading down into this depression from the head of the rock glacier stands at $38^{\circ}$ and was observed to be actively failing in March 1976. Only at the extreme eastern edge is the head of the rock glacier attached to the talus below the headwall (Fig. 2).

The cirque headwall adjacent to the head of the rock glacier is approximately $250 \mathrm{~m}$ high and is cut by a complex gully system which leads into three major chutes. These chutes direct rockfalls along a $100 \mathrm{~m}$ length of cliff foot which lies directly behind the head of the rock glacier (Fig. 2).

\section{INTERPRETATION}

Two main types of rock glacier have been identified in alpine areas; these are the "icecemented" and "ice-cored" types (Potter, 1972, p. 3027). The first appears to develop as a result of the flow of talus with interstitial ice, and requires that the climate be cold enough for permafrost to exist (Washburn, 1973). On the other hand, the "ice-cored" rock glacier is thought to develop as a result of glacier ice becoming covered with rock debris and its development depends on the initial existence of a glacier, the volume of debris supply, and the rate of glacier ablation, rather than purely climatic conditions (Whalley, 1974). Thus, "ice-cored" rock glaciers may occur in environments with a mean annual temperature (MAT) above $0{ }^{\circ} \mathrm{C}$, and examples have been recorded in the Akureyri area of north Iceland where the MAT is $+4^{\circ} \mathrm{C}$.

Although the two main types of rock glacier have different origins, they may be morphologically similar (Corte, 1976; White, 1976). This is thought to be especially true where they occur as relict features. However, studies on active rock glaciers, for example, in the western Yukon, indicate that features like saucer-shaped depressions at the rock-glacier head, lateral longitudinal furrows, central meandering furrows, and collapse pits may be indicative of ice cores (Vernon and Hughes, 1966).

Morphological features associated with the Cooper Sound rock glacier suggest that it is of the ice-cored type. In particular, the deep depression between the rock-glacier head and the cirque walls behind may indicate the former presence of a glacier. This depression is similar to those described behind ice-cored rock glaciers elsewhere (White, 1976). Although no direct evidence for the presence of an ice core was observed in the field, the activity and steepness of many of the debris slopes on and around the Cooper Sound rock glacier indicate inherent instability which may be the result of an ice core moving or melting out. Lack of melt-water activity suggests the former is more likely.

At the present time, the Cooper Sound rock glacier is "relict", at least in terms of debris supply, since a depression separates the head of the feature from the debris sources above (Fig. 2). Although it is possible that debris supply is achieved over an annual snow-pack which 
fills the depression during spring and early summer, the depth of snow required makes it unlikely, especially when altitude and southerly aspect are taken into account. The depression was unfilled when air photographs were taken by a helicopter from HMS Endurance in November 1974 (RN $13 / 74$ Unclassified). It is more likely that a perennial snow/ice body did occupy the depression during a colder period but has since melted.

The possible effect of climatic change makes it worthwhile examining the alternative hypothesis that the rock glacier originated from frozen talus. If this is the case, permafrost conditions should have existed at least in the area of its source. Typical figures for dry and saturated adiabatic lapse-rates are $1.0 \mathrm{deg} / 100 \mathrm{~m}$ and $0.6 \mathrm{deg} / 100 \mathrm{~m}$ (Laaksonen, 1976), respectively, and Smith (1960[b]) gave a figure of $0.7 \mathrm{deg} / 100 \mathrm{~m}$ for the lapse-rate in the Cumberland Bay area of South Georgia. Given that the MAT is around $2.1^{\circ} \mathrm{C}$, the altitude of permafrost in South Georgia at present is, at a minimum, around $200 \mathrm{~m}$ but is more likely to be near $300 \mathrm{~m}$. The altitude of the head of the Cooper Sound rock glacier is $200 \mathrm{~m}$, probably below the lower limit of permafrost at present. However, taking into account local effects such as aspect, it is possible that a 1-2 deg drop in MAT could create the conditions required for an icecemented rock glacier to develop. Thus, only a slight change from present climatic conditions could permit an ice-cemented rock glacier to develop at the altitude of the head of the Cooper Sound example.

Despite the above argument, an origin from the flow of frozen talus is not thought to be valid for the Cooper Sound rock glacier, because of the spatial separation that exists between the head of the rock glacier and the source talus. Since ice-cemented rock glaciers develop directly from frozen talus and are contiguous with it, the separation is more likely to be due to the former presence of an ice mass. Thus it is on morphological rather than climatic grounds that the Cooper Sound rock glacier is thought to be of the ice-cored type.

In this particular location, burial of glacier ice may be explained by a high potential debris supply from the dissected cirque headwall behind, and the restricted length of cliff foot receiving this debris. Comparison between potential debris source areas and area of receiving glacier has been made for several depositional landforms in the Cooper Bay-Hamilton Bay area (Birnie, unpublished). These include a range of features from pro-talus ramparts to ice-cored moraines. The results suggest that the fundamental constraints to rock-glacier development are:

(1) Contributing cliff area, which appears to determine debris supply.

(2) The area of the receiving glacier.

The combination of small glacier and high potential supply of debris at the rock-glacier site appears to be unique in the Cooper Bay-Hamilton Bay area. One particular factor here is the complex gully system in the cirque headwall, which greatly increases the potential generating area. This is to be compared with the planar cliff faces contributing debris to several of the protalus ramparts (Fig. 2). These conclusions are comparable to those of Whalley (1974), who showed that the development of a rock glacier from Arapaho South Glacier in Colorado was due to the high volume of debris supply it received per unit area.

\section{DEVELOPMENT CHRONOLOGY}

The development of the Cooper Bay rock glacier appears to have taken place in four phases, shown by the four distinct morphological units identified within the feature. In addition, the 
presence of till beneath the outermost ridges indicates that the cirque which the rock glacier now occupies was previously occupied by an ice glacier.

Clapperton and others (1978) identified four glacial stages in South Georgia:

(1) An ice-cap glaciation extending beyond the present coastline, with a maximum 17000 years B.P. $\left(\mathrm{T}_{4}\right)$.

(2) A more limited "valley glaciation" occurring before 10000 years B.P. $\left(\mathrm{T}_{3}\right)$ and reaching up to $5 \mathrm{~km}$ beyond the present ice margins.

(3) and (4) Two minor Neoglacial advances with maximum extents 200 years B.P. $\left(\mathrm{T}_{2}\right)$ and 24 years B.P. $\left(\mathrm{T}_{1}\right)$ of less than $1 \mathrm{~km}$ beyond present.

Rock-glacier development is complex and depends not only on climatic factors but also on those governing debris supply and the flow of rock/ice admixes. This limits any direct correlation of rock-glacier development with glacial history. It is, however, possible to suggest that, in view of the extensive ice cover on South Georgia during the ice-cap and valley-glacier stages, it is likely that the till exposed beneath the outer ridges of the Cooper Bay rock glacier is a correlative of at least one of these stages. If this is the case, it is likely that this rock glacier has developed within the last 10000-17000 years. Until a properly calibrated lichen-growth curve is established for South Georgia, more accurate dating is not possible, although in view of the extremely degraded nature of the outer ridges of the feature, it is not considered possible that this rock glacier has developed solely in association with the most recent climatic fluctuation of the last 200 years.

\section{Binary Peaks Rock Glacier}

The Binary Peaks rock glacier is developed down-slope from a talus apron (Fig. 4) between 80 and $100 \mathrm{~m}$ long, and about $100 \mathrm{~m}$ high. Above the talus is a cliff face between $5 \mathrm{~m}$ and $20 \mathrm{~m}$ high. The rock glacier is lobate (Fig. 5) and is composed of fragments of greywacke up to $4.5 \mathrm{~m}$ in diameter, but fragments over $2 \mathrm{~m}$ are rare. The most common visible size ranges are $30-50 \mathrm{~cm}$ and $100-200 \mathrm{~cm}$. Fine-size components were not observed.

The main surface features of the Binary Peaks rock glacier are a series of at least nine arcuate ridges from $3 \mathrm{~m}$ to $6 \mathrm{~m}$ high, with steeper distal slopes of between $21^{\circ}$ and $37^{\circ}$. The ridges outside the one marked $\mathrm{Y}$ on Figure 4 are degraded and over-riden at the south-western edge by the moraine of a former cirque glacier (Fig. 4). Thus two distinct ridge types are defined morphologically. No vegetation or weathering-rind data were collected.

The toe of the rock glacier lies at $363 \mathrm{~m}$ a.s.l. and it is $175 \mathrm{~m}$ long. The height difference between the head and the terminus is $41 \mathrm{~m}$. Above the highest ramp the average surface slope is $9^{\circ}$.

\section{INTERPRETATION}

The Binary Peaks rock glacier differs from the Cooper Sound feature both in terms of shape and relationship to rockwall sources. Whereas the Cooper Sound rock glacier is of the "spatulate" type recognized by White (1976), the Binary Peaks example is more akin to White's "lobate" type which commonly occurs below talus. Indeed, the Binary Peaks feature, unlike the Cooper Sound one, is directly linked to the talus at present. This, together with the more simple 

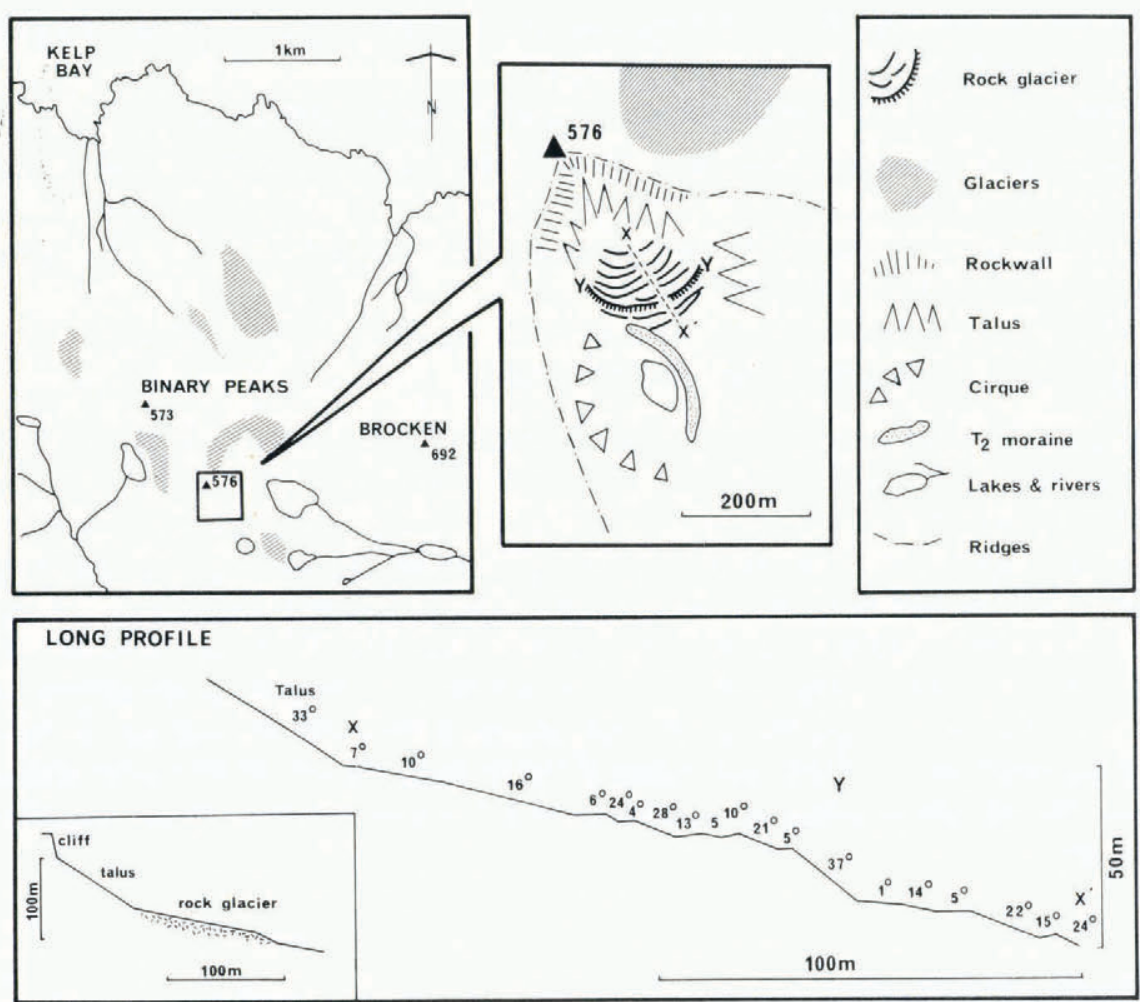

Fig. 4. Location and geomorphic setting of the Binary Peaks rock glacier (based partly on 182/500/2/70 of 42 Survey Engineer Regiment).

morphology of the Binary Peaks rock glacier, suggests that it may be an example of an "icecemented" type (Potter, 1972).

In December 1976, excavation revealed ground ice $25 \mathrm{~cm}$ below the surface of frost-sorted till, about $200 \mathrm{~m}$ from the Binary Peaks rock glacier and at approximately the same altitude as its toe $(360 \mathrm{~m})$. Although permafrost does not occur at low levels in South Georgia (Smith, 1960[a]; Thom, unpublished), given the altitude of this site, in relation to a freezing level of between 200 and $300 \mathrm{~m}$ mentioned previously, it is likely that this was perennial rather than seasonal ground ice. It would seem fair therefore to assume that, although comprising different sediment, permafrost would also occur at depth in the Binary Peaks rock glacier.

These observations, together with the lack of surface features considered diagnostic of the presence of an ice core, and the fact that the rock glacier is contiguous with the talus, suggest it may be "ice-cemented". Such an origin may partly explain the order-of-magnitude size difference between it and the Cooper Sound example.

\section{DEVELOPMENT CHRONOLOGY}

The morphological characteristics of the Binary Peaks rock glacier described above suggest that it has experienced two phases of development. The outermost ridges have at one time been 


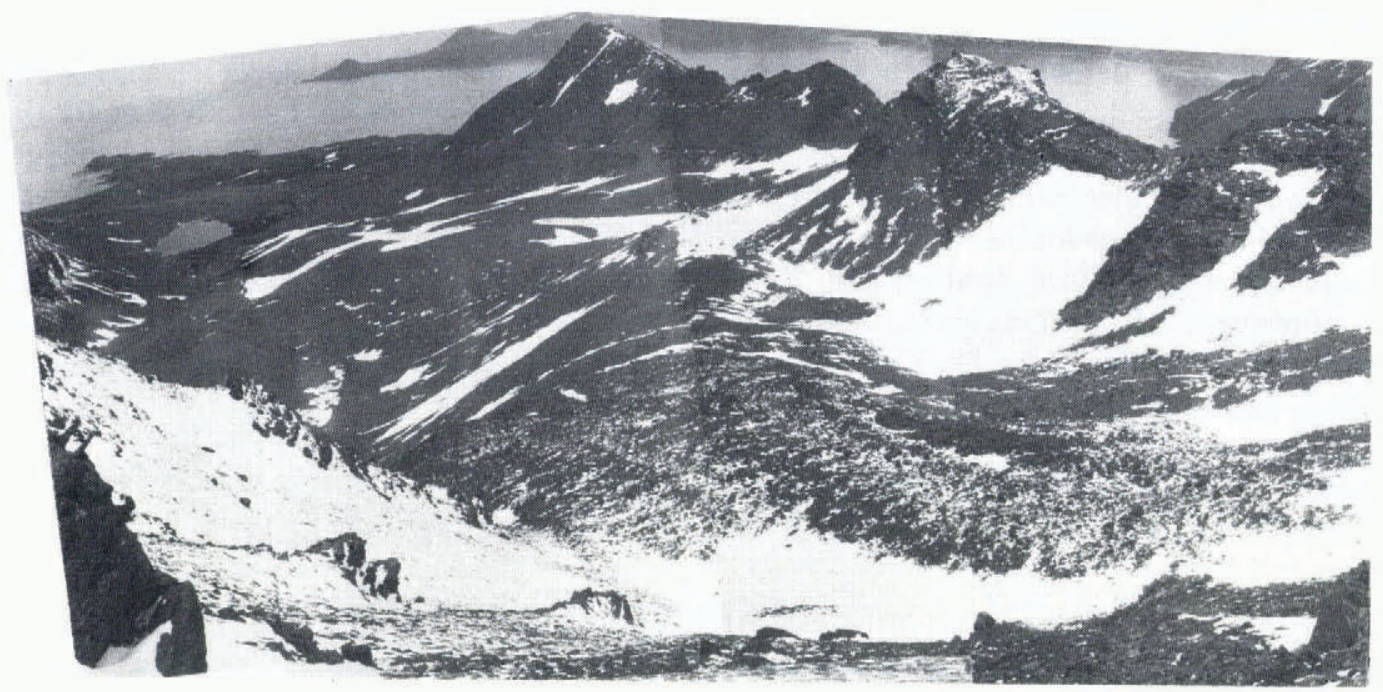

Fig. 5. View south-east across the Binary Peaks rock glacier. The feature occupies the foreground and the flow direction is from right to left.

overtopped by till from an adjacent glacier. On the basis of spatial association, this till is dated as being from the 200 years B.P. $\left(\mathrm{T}_{2}\right)$ glacial advance. Therefore, the outer part of the rock glacier is older than this.

The outermost ridges rest on till. This till is spatially contiguous with deposits of the "valley glacial" phase $\left(\mathrm{T}_{3}\right)$ of glacial activity and is therefore dated as being pre-10 000 years B.P. Thus the stratigraphical relations of the outer ridges of the Binary Peaks rock glacier suggest that the initial development of the feature occurred post-"valley glaciation" $\left(\mathrm{T}_{3}\right)$ but pre-200 years B.P. $\left(\mathrm{T}_{2}\right)$.

\section{CONCLUSION}

The presence of these rock glaciers in the maritime environment of South Georgia is contrary to some published views on rock-glacier distribution. For example, it has been stated that "both rock glaciers and ice-cored moraines are prevalent in glaciated or glacierized areas where the climate is somewhat continental" (Østrem, 1964; Guiter, 1972). Both forms are rare where the "climate is maritime" (from Whalley, 1974). However, the observations in South Georgia are not entirely unpredictable. It has been suggested here and elsewhere (Whalley, 1974) that the conditions required to initiate "ice-cored" rock-glacier development are high debris supply coupled with low receiving glacier area. For example, the Cooper Sound rock glacier is thought to have developed as a response to an extensive cliff-gully system debouching material along a restricted length of cliff foot. These observations confirm the theory that the juxtaposition of "large" cliffs and small glaciers may happen in any glaciated environment irrespective of zonal climate, and one possible explanation for the rarity of rock glaciers in any environment is the lack of suitable niches of this type. 


\section{ACKNOWLEDGEMENTS}

The authors are indebted to Dr R. M. Laws for allowing them to work under the auspices of the British Antarctic Survey between 1974 and 1977, and to the late Professor K. Walton for the facilities in the Geography Department at the University of Aberdeen. Facilities for the preparation of this paper were provided by Professor W. B. Johnston of the Geography Department, University of Canterbury, Christchurch, New Zealand. Financial support came from the UK Natural Environment Research Council. Particular thanks are due to Dr J. Hansom, Dr J. Gordon, and C. Johnston for assistance in the field, Dr G. C. Stove for help with photogrammetry and Drs C. M. Clapperton and D. E. Sugden, who critically commented upon drafts of the paper.

MS. received 2 July 1981 and in revised form 17 December 1981

\section{REFERENCES}

Bell, C. M., and others. 1977. The geology of part of an island-arc marginal basin system in southern South Georgia, by C. M. Bell, B. F. Mair, and B. C. Storey. British Antarctic Survey Bulletin, No. 46, p. 109-27.

Birnie, R. V. Unpublished. Rock debris transport and deposition by valley glaciers in South Georgia. [Ph.D. thesis, University of Aberdeen, 1978.]

Clapperton, C. M., and others. 1978. Glacier fluctuations in South Georgia and comparison with other island groups in the Scotia Sea, by C. M. Clapperton, D. E. Sugden, R. V. Birnie, J. D. Hanson, and G. Thom. (In Zinderen Bakker, E. M. van, sr, ed. Antarctic glacial history and world palaeoenvironments. International Council of Scientific Unions. Scientific Committee on Antarctic Research. Proceedings of a symposium held on 17th August, 1977 during the Xth INQUA Congress at Birmingham, U.K. Rotterdam, A. A. Balkema, p. 95-104.)

Corte, A. E. 1976. Rock glaciers. Biuletyn Peryglacjalny, No. 26, p. 175-97.

Gordon, J. E., and others. 1978. A major rockfall and debris slide on the Lyell Glacier, South Georgia, [by] J. E. Gordon, R. V. Birnie, and R. J. Timmis. Arctic and Alpine Research, Vol. 10, No. 1, p. 49-60.

Guiter, V. 1972. Une forme montagnarde: le rock-glacier. Revue de Géographie Alpine, Tom. 60, Fasc. 3, p. $467-87$.

Laaksonen, K. 1976. The dependence of mean air temperatures upon latitude and altitude in Fennoscandia (1921-1950). Annales Academiae Scientiarum Fennicae, Ser. A III, Tom. 119.

Østrem, G. 1964. Ice-cored moraines in Scandinavia. Geografiska Annaler, Vol. 46, No. 3, p. $282-337$.

Pepper, J. 1954. The meteorology of the Falkland Islands and Dependencies, 1944-1950. London, Falkland Islands and Dependencies Meteorological Service.

Potter, N., jr. 1972. Ice-cored rock glacier, Galena Creek, northern Absaroka Mountains, Wyoming. Geological Society of America. Bulletin, Vol. 83, No. 10, p. 3025-57.

Richards, P. A., and Tickell, W. L. N. 1968. Comparison between the weather at Bird Island and King Edward Point, South Georgia. British Antarctic Survey Bulletin, No. 15, p. 63-69.

Skidmore, M. J. 1972. The geology of South Georgia: III. Prince Olav Harbour and Stromness Bay areas. British Antarctic Survey. Scientific Reports, No. 73.

Smith, J. 1960[a]. Cryoturbation data from South Georgia. Biuletyn Peryglacjalny, No. 8, p. 73-79.

Smith, J. 1960 [b]. Glacier problems in South Georgia. Journal of Glaciology, Vol. 3, No. 28, p. $705-14$.

Thom, G. Unpublished. Patterned ground in South Georgia, Antarctica. [Ph.D. thesis, University of Aberdeen. 1981.]

Vernon, P., and Hughes, O. L. 1966. Surficial geology, Dawson, Larson Creek, and Nash Creek map-areas, Yukon Territory. Canada. Geological Survey, Bulletin 136.

Washburn, A. L. 1973. Periglacial processes and environments. London, Edward Arnold.

Whalley, W. B. 1974. Rock glaciers and their formation as part of a glacier debris-transport system. University of Reading. Dept. of Geography. Geographical Papers, No. 24.

White, S. E. 1976. Rock glaciers and block fields, review and new data. Quaternary Research, Vol. 6, No. 1, p. 77-97. 